Section A: Research Articles

\title{
Dona Barbara, from an Amazon Ogress to a Loving Mother: A Tale of Revenge and Love
}

\author{
Bam Dev Adhikari \\ Associate Professor of English Trichandra Campus, \\ Tribhuvan University, Kathmandu, Nepal.
}

\section{Introduction}

Venezuelan novelist Romulo Gallegos' novel Dona Barbara (1929) is set in Venezuelan llanos and it depicts the conflict between barbarism and civilization that is represented by the figure of an amazon ogress and the figure of a good mother of the same woman named Dona Barbara. The specific setting of the novel, the Altamira ranch is a huge estate in the wildest section of the Arauca River basin of Venezuela, a ranch that was established early in the history of the country's cattle business. Altamira gets neglected by its owner for years until Santos Luzardo, the successor of the ranch, a lawyer and a Ph. D. from the University of Carcass arrives there and tries to set the anarchy in order. On the other hand, the Altamira ranch borders the El Miedo ranch, owned by a ruthless woman, an amazon named Dona Barbara, who becomes the owner of the ranch by the use of tricks and treachery. Dona Barbara tries to expand her ranch by trespassing the neighboring ranches with the forces of witchcraft, superstition and deceit. As Skurski calls her, "a personification of rural despotism" (617), she rules the llanos for pelf and power with revenge from men as her central motive. Brian Gollnick comments on this conflict as "Santos Luzardo triumphing through a plan to rationalize territorial organization and agriculture under an enlightened authority which contrasts to Dona Barbara's black magic and despotic charisma" (450). Thus, the novel establishes two lines, in the beginning, the line of civilization represented by Santos Luzardo and the line of barbarism represented by Dona Barbara. The novelist has associated the line of barbarism with the ogress figure and civilization with the mother figure of the same woman, Dona Barbara.

The Oxford dictionary defines ogress as "a female monster in fairy tales and popular legend, usually represented as a hideous giant who feeds on human flesh." The ogresses have appeared frequently in mythology, folklore and fiction throughout the world literature. Some of the examples of fairy tales that portray ogresses are "Hop-o'-My-Thumb", "Puss in Boots", "Sleeping Beauty", "The Bee and the Orange Tree", "Tom Thumb", "Hansel and Gretel" and "The Little Red Riding Hood." Joseph Campbell associates ogresses with cannibal mothers, who lure the children towards the candy house in order to lure them and eat them. He adds, "Cannibal ogresses appear in the folklore of peoples, high and low, throughout the world; and on the mythological level the archetype is even magnified into a universal symbol in such cannibal mother goddesses as the Hindu Kali, the Black one" (68). J. Van Baal also gives a similar definition of an ogress. According to him, the ogresses are, "supernatural, infra-human beings: they eat their own people, suffer from an abundance of lice and find their way by scent" (100). 
The idea of the ogress can be found in literature, more broadly in metaphoric representation and the novelist calls Dona Barbara an ogress not in literal but in a metaphorical sense. As an ogress, Dona Barbara is initially portrayed as a devourer of men and a bad mother.

We can find innumerable instances of good and bad mothers from myth to modernity. The famous 'Solomon's Judgement' is an anecdote in the Bible which dramatizes two women claiming a single baby. As each of them claims the child her own, king Solomon orders his men to cut the child into two halves so as to give each woman a piece. The real mother disowns the baby and the king knows who the authentic mother is. The real mother sacrifices her baby thinking at least it would survive even with another woman. Amelia E. Bar explains this sacrifice, "For mother-love is the spirit of self-sacrifice even unto death and self-sacrifice is the meat and drink of all true and pure affection" (408). Dona Barbara is portrayed as a bad mother throughout the novel but the story takes a dramatic twist at the end that makes the reader forget Dona Barbara's mistreatment of her daughter throughout her life. Blind in her goal of revenge and restitution, Dona Barbara forgets her maternal duty towards her daughter Marisela and runs after a wild adventure of her men devouring journey of an ogress, but the 'bad mother self' finally surrenders before her 'good mother self' and she makes a motherly sacrifice for her daughter.

\section{Dona Barbara: The Birth of an Ogress}

The novel dramatizes racial discrimination in the Americas in the nineteen-thirties when the nonwhites were regarded as non-human. It was a time when even the rape and sale of Indian, black and Mestizo girls were rampant in the whole South American continent. A Mestizo girl Barbarita, a cook in a seafaring pirogue is gang-raped and her prospective suitor Hasdrubal is brutally murdered by five young men and the girl is nearly sold to a Turk, a jungle man with a harem of wives of all races and age groups. One of the rapists remarks, "Now we can sell her to the Turk and the twenty ounces he offered will be enough" (58). The girl somehow escapes from being sold and develops only one motive in her life, the motive of revenge with the race of men. The narrator comments that "she lived only to gain the secret knowledge necessary for bewitching men" (59). Barbarita does all she can in order to be avenged with her wrongdoers and these include from witchcraft to other superstitious extravagances. Her sex appealing beauty and body structure also help her to incarnate herself into men trapping ogress. The novelist adds, "Just so it was some years before the mestiza's hot sensuality combined with her bitter loathing for men" (61). In the novelist's opinion, she looks at once "wild, beautiful and terrible" (Barbara 70). She becomes Dona Barbara from Barbarita and starts her men devouring wild journey using trickeries of all sorts including her feminine appeal, witchcraft, bribes, warning, intimidation and so on. Julie Skurski gives her comments on this transformation.

In the past, she had been simply Barbarita an innocent, untutored girl who yearned for love and whose youthful self is later mirrored in her daughter, Marisela. Now she has become the feared Dona Barbara, a destructive figure of undifferentiated sexual energy, with male and female 
impulses mixing in a monstrous hybrid combination, driven to conquer men in revenge for her own conquest. She is the creation of a monstrous act ... (623).

Within a few years, the innocent girl Barbarita yearning for the love of a man called Hasdrubal gets transformed into a man hunting amazon, an ogress, whose seen and unseen activities are oriented only towards being avenged of her past torture and horror.

\section{Dona Barbara's Wild Journey of an Ogress}

Dona Barbara becomes so influential in the Arauca basin that myths are created and circulated in the neighboring regions. While sailing towards the llanos, a boatman remarks, "Do you know this Dona Barbara of whom there are so many tales told in Apure country" (23). Finding Santos Luzardo being inquisitive about the woman, the boatman adds, "They say she is a desperate woman and leader of a troop of bandits. She orders to assassinate anyone who shows any sign of opposing her" (23). When Santos Luzardo becomes more curious about the woman, the boatman warns him, "She's a woman who has pocketed heaps of men and she never misses when she begins sweet talking. She gives a man a love potion and ties him to her apron string and then she does what she likes with him because she knows witchcraft" (26). The novelist even associates Dona Barbara with a fierce alligator, "That's the one-eyed alligator of the Bramador pass, and bullets don't go into him" (29). Like the one-eyed alligator of the Bramador pass, Barbara develops a one-sided plan to usurp the property in the llanos, be it legally or illegally, be it by love or by threats and be it by rational means or superstitious means. She is so absorbed in her mission that even motherhood cannot spot her in the wild journey of revenge.

Motherhood is considered an important achievement for a woman but this emotional feeling does not stop Barbara in her wild race of bewitching men for a property. Barbarita becomes Barbara and Barbara becomes a mother but motherhood does not bring any changes in her men devouring wild adventure. The narrator comments on her character, "Not even motherhood could quench the ogress' hatred. On the contrary, it deepened that hatred. A child in her womb was to her another victory for male, a new injury undergone" (62). Usually, it's men who make the women suffer by impregnating them but in Barbara's case, it's the other way round. Barbara gives birth to a daughter and she gives the baby to her father Don Lorenzo, who bears the entire responsibility of rearing the girl. The father of her daughter becomes her first quarry of her men hunting game. By tricks and treachery, she succeeds in snatching his land from Lorenzo and she names it El Miedo meaning 'fear' in Spanish. Poor Lorenzo goes to a hut in the palm groove where the girl Marisela grows without motherly affection at all. Dona Barbara abandons her daughter thinking she can be a hurdle in her mission of taking revenge with the race of men.

Barbara uses the ranch El Miedo as a base or starting point for her further trespassing purposes. Her major plan is to occupy the bordering ranch called Altamira belonging to Santos Luzardo, an educated and civilized man. The novel depicts the conflict between Dr. Luzardo, an educated man and a lawyer and Dona Barbara, an uncivilized ogress. The conflict between them can be interpreted as a struggle between civilization and barbarism in the South American continent, a 
leitmotif that stirred the writers since the publication of Argentine novelist Domingo Faustino Sarmiento's Facundo. Melvin S. Arrington remarks, "The conflict on the Venezuelan llanos between Santos Luzardo and Dona Barbara is a microcosmic re-enactment of armiento's archetypal struggle between civilization and barbarism" (631). Santos Luzardo wants to protect Altamira by building a fence and Barbara wants to foil his attempts. Barbara wants to conquer the entire Arauca basin using weapons like love, ticks and treachery. The novelist comments, "Her greed loosed, she determined to own the entire basin of the Arauca, . . . began to sue all her neighbors, winning through the corruption of the judges whatever she could not gain from justice" (66). She acts as if her aim in life is to bewitch men and acquiesce their property and she gets uninterrupted success and her final target becomes the Altamira ranch.

Dona Barbara reaches forty and even at the age of forty, she harbors the same hatred towards men and her lust for a property does not diminish. The narrator comments on her character, "She was the notorious Dona Barbara: a compound of lust greed, and cruelty with a pathetic little remnant in her bitter heart of something pure and sad the memory of Hasdrubal (71). Then the narrator passes comments on the memory "The memory of Hasdrubal always came to her when she encountered a man who was a worthy prey" (71). Her mission of trapping men and hoarding property goes on uninterrupted and she even does not have time to think about her daughter, who spends the life of a pauper. The mother gets richer and richer but the daughter always remains in destitute. The narrator comments on the mother-daughter relationship, "Nothing referring to Marisela had ever interested Dona Barbara for she had never felt toward the girl even the instinctive love of an animal for her suckling young" (269). However, the mother figure inside Barbara remains subdued; it does not disappear from her heart and waits for the proper moment for the eruption.

Barbara's divided self between an ogress and a mother comes to the surface when Marisela becomes an adult girl. She wants to send her daughter far from that area so that she would not come face to face with her and create disturbance in her mission. She sends her servant to Marisela saying, "Take these. Carry them to her. Say that there are three hundred pesos here. Tell her to go away from here with her father and to do every possible thing to keep me from ever hearing of her again" (480). If she had no feelings toward her daughter, she would not have thought about her at all. Thinking that her subdued feeling towards her daughter can overcome her and she would deviate herself from her mission, Barbara wants to send her daughter far from her. The daughter too does not have any feelings towards her mother. She does not want to take this money but she does not have another way to save herself from Senor Danger either. Senor Danger, an American is trying to marry Marisela by bribing her addicted father with alcoholic drinks. Marisela replies to Barbara's man, "No matter how much you wash them, it will always disgust me too much them. Leave them there. It's not the handkerchief that I mind"(481). The money she receives from her mother does not rouse any feelings towards her mother. The mother-daughter cleavage remains as intact as before. Dona Barbara believes that she would weaken Santos Luzardo by witchcraft and she gets his body parts measured by the help of cords. Marisela wants to save Dr. Luzardo from being victimized by Barbara's witchcraft and goes 
straight to her mother's room to snatch those ropes. Dona Barbara sees her daughter after years, gets dazzled by her body and beauty and hesitates to attack her. Both mother and daughter make of tug of war, each trying to get the rope for herself and, for the first time, Marisela speaks to her mother an insulting word, "Witch!" (404). The narrator comments on mother-daughter confrontation, "The conflict in Dona Barbara's heart, when she heard from her own daughter the insulting epithet no one had ever dared to pronounce in her presence, was like the collision of two masses hurtling together and falling shattered in ruins" (404). It's rare in real life or even in the literature to find an instance where her own daughter blames her mother 'a witch.' Dona Barabara cannot hurt her daughter because of the unexpected presence of Santos Luzardo and the relation between the mother and the daughter remains as divided as before.

\section{The Metamorphosis of a Mother from an Ogress}

Dona Barbara has been portrayed as an enigmatic character. Her feeling towards Santos Luzardo remains ambiguous throughout the novel. On the one hand, she wants to occupy more and more territory of his property Altamira, and on the other hand, she has a longing towards him. Her submerged feeling of love towards Santos Luzardo comes on the surface when her men report that Marisela and Santos Luzardo are getting married. Dona Barbara approaches the wedding couple and points her revolver straight towards her daughter's breast. But things do not go as she had planned. She cannot fire her gun at her own daughter. The narrator describes, "But as if that tiny beam held all the weight of the star from which it was reflected, the revolver descended without a shot" (570). Dona Barbara stops and gazes at the couple yearning for a new life. Unexpectedly, a maternal sentiment comes to her mind and she speaks,

"He is yours. May he make you happy" (571). An unexpected metamorphosis takes place; a mother is reborn from an ogress. Kurt L. Levy comments on this metamorphosis, "so the crueldespot (Barbara) becomes increasingly disoriented: the grasslands' sphinx has turned into a sphinx unto herself" (119). Julie Skurski relates it with Barbara's memory, "But she suddenly 'sees' as in a vision, her former self incarnated in the person of Marisela and decides instead to leave the llanos" (624). A new woman is born in Dona Barbara, a mother becomes dominant in place of the ogress and she remembers her old lover Hasdrubal and thinks that the ghost in her mind has found an easy outlet.

Santos Luzardo was told about one-eyed alligator of the Bramador Pass on the boat while he was heading towards Arauca. The beast is ambushed and killed by Luzardo's men just before Barbara surrenders in front of her daughter. Carlos J. Alonso associates the death of the beast with the powerlessness of Barbara. He argues, "Given the identification of the beast with Dona Barbara explicitly advanced at the beginning of the scene, the contest between Santos Luzardo's men and the alligator is depicted by the text as alluding allegorically to the struggle between Luzardo and Dona Barbara" (121). The identification of Dona Barbara with the oneeyed alligator and the death of the beast signals the end of Barbara's despotic regime in the llanos and establishment of order and justice. The victory of Santos Luzardo is the victory of Marisela as well because they are getting married and uniting two estates El Miedo and Altamira into one estate. The end of 
one-eyed alligator, symbol of Barbara's fierce self indicates the birth of good woman, a mother in Dona Barbara.

When the ogress is no longer present in Dona Barbara, the ranch seems alien to her and she feels restless in her own land where she had exercised her power for decades. Hurriedly she reaches her home and writes the last will in a letter to Santos Luzardo, which says, "I have no other heir but my daughter Marisela and I hereby recognize her as such before God and men. Take charge of arranging all the details of the legacy for her" (576). Dona Barbara gallops down the Arauca but nobody knows where she has gone. The novelist ends the novel with a sentence, "The name of El Miedo disappeared from the Arauca, and all the lands once more became known as Altamira" (578). As the tale of revenge ends in the love of a mother and the ogress fades into the mother, the novel ends in a note that ultimately civilization defeats barbarism.

\section{Works Cited}

Alonso, Carlos J. The Spanish American Regional Novel: Modernity and Autochthony. Cambridge University Press, 1990.

Arrington, Melvin S. "Dona Barbara." Encyclopedia of Latin American Literature. Ed. Verity Smith. Fitzroy Dearborn Publishers, 1997. 631-633.

Baal, J. Van. Jan Verschueren's Description of Yei-Nan Culture. Brill, 1998.

Barr, Amelia E. "Good and Bad Mother." The North American Review, vo.156, no.437, April 1993, pp. 408-415.JSTOR, www.jstor.org/stable/25103114.

Campbell, Joseph. The Mask of the God: Primitive Mythology. Secker and Warburg, 1960.

Gallegos, Romulo. Dona Barbara. Trans. Robert Malloy. The University of Chicago Press, 1931.

Gollnick, Brian. "The Regional Novel and Behind." The Cambridge Companion to Latin American Novel. Ed. Efrain Kristal. Cambridge University Press, 2005.

Levy, Kurt L. "Dona Barbara: The Human Dimension.” The International Fiction Review, vol.7, no. 2, 1980, pp. 118-122. https://journals.lib.unb.ca.

Skurski, Julie. "The Ambiguities of Authenticity in Latin America: Dona Barbara and the Construction of National Identity." Poetics Today, vol. 15, no.4, winter 1994, pp. 606642. JSTOR, www.jstor.org/stable/1773103. 